УДК 631.356.22

DOI 10.36910/6775-2313-5352-2020-17-8

Дубчак Н.А., Семенів І.І., Носко В.Л.

ВП НУБіП України «Бережанський агротехнічний інститут»

\title{
РЕЗУЛЬТАТИ ЕКСПЕРИМЕНТАЛЬНИХ ДОСЛІДЖЕНЬ ОЧИСНОЇ СИСТЕМИ ВОРОХУ КОРЕНЕПЛОДІВ
}

\begin{abstract}
Анотація. $\quad$ с статті наведено одержані результати проведених польових експериментальних випробувань модернізованої коренезбиральної машини МКК-6, яку обладнано комбінованою системою для очистки кормових буряків від різного роду забруднень при їх збиранні. На основі експериментальних результатів виведено рівняння регресії, які характеризують зміну загальної забрудненості вороху коренеплодів різними домішками та побудовано графічні залежності загальної забрудненості вороху кормових буряків, пошкоджень коренеплодів, забрудненості коренеплодів рослинними рештками $і$ кількості налиплого трунту на поверхні тіла коренеплодів залежно від зміни кутової швидкості обертання гвинта та діаметра очисних пружних елементів. При аналізі залежностей виявлено, що загальна забрудненість вороху коренеплодів залежно від кутової швидкості обертання гвинта змінюється за параболічною функиією, яка має яскраво виражений оптимум. Також зв'ясовано, що основним фактором, який впливає на кількість налиплого трунту на поверхні тіла коренеплодів є діаметр очисних пружних елементів. При його збільшенні кількість налиплого трунту на поверхні тіла коренеплодів значно зменшується при всіх значеннях кутової ивидкості обертання гвинта.
\end{abstract}

Ключові слова: сепаруючий робочий орган, транспортно-технологічна система, коренеплоди, ворох, коренезбиральна машина, гвинт, кутова швидкість, очисний елемент.

Вступ. Аналіз використання розроблених в останні роки в Україні і за кордоном сепаруючих робочих органів транспортно-технологічних систем коренезбиральних машин у різних грунтово-кліматичних умовах та зонах показує, що задовільна якість очищення коренеплодів кормових буряків від домішок може бути одержана лише в оптимальних умовах збирання, тобто при необхідній вологості грунту, задовільній забур'яненості посівів і використанні конкретної для даної культури конструктивно-технологічної схеми сепаруючого робочого органа. Якщо ж цих умов не буде дотримано при збиранні, то в протилежному випадку пошкодження коренеплодів, забрудненість вороху будуть мати певні коливання [1]. Ефективність і якість роботи машин у значній мірі залежить від конструктивно-компонувальної схеми та процесу роботи робочих органів очисників вороху, які повинні відокремити із складу поступаючого вороху не менше $92 \%$ домішок за вихідними вимогами до коренезбиральних машин, при цьому допустимі пошкодження не повинні перевищувати межу 15 \% [2].

Огляд та аналіз попередніх досліджень. Головним загальним недоліком роботи очисних систем вороху кормових буряків у важких умовах збирання $\epsilon$ те, що очищення коренеплодів від домішок відбувається в одному технологічному потоці, коли коренеплоди і домішки пересуваються по поверхні сепарувальних робочих органів у одному повздовжньому або поперечному напрямках, що значно утруднює процес відокремлення домішок від коренеплодів [3, 4]. Нами створена комбінована очисна система вороху коренеплодів, конструктивно-технологічна схема та принцип роботи якої наведено у праці [5].

Мета досліджень. Метою даних досліджень $є$ підвищення ефективності сепарації домішок вороху коренеплодів кормових буряків шляхом удосконалення очисної системи коренезбиральної машини.

Виклад основного матеріалу. Виробничі випробування та експериментальні дослідження модернізованої коренезбиральної машини МКК-6 (рис. 1), яку було обладнано очисною системою вороху [4], проведено в дослідному господарстві Українського центру випробування техніки Київської області при збиранні кормових буряків сорту "Екендорфський". Основні конструктивно-технологічні параметри очисної системи при проведенні випробувань були наступні: кутова швидкість обертання гвинта 12,5 рад/с; діаметр гвинта - 0,6 м; крок гвинта - 0,5 м; висота витка гвинта - 0,25 м; кутова швидкість відминальних вальців - 40 рад/с; діаметр відминальних вальців - 0,12 м: діаметр очисних елементів 4 мм, поступальна швидкість руху полотна гірки - 1,3 м/с. При проведенні 
експериментальних досліджень кутову швидкість обертання гвинта змінювали в межах $9,5 \ldots 15,5 \mathrm{paz} / \mathrm{c}$, а діаметр очисних елементів - у межах 2...6мм. Інші показники технічної характеристики коренезбиральної машини МКК-6 відповідали заводським параметрам. Характеристика ділянки поля, на якій проведено випробування, така: тип грунту - чорнозем середньогумусний, середньо-суглинковий, щільність грунту в шарі $0 \ldots 10$ см - 1,3 мПа, вологість грунту в шарі $0 \ldots 10$ см - 17,7\%, урожайність коренеплодів - 95,8 т/га, маса бур'янів 3 $1 \mathrm{~m}^{2}-0,15 \kappa \Gamma$.

Показники якості роботи коренезбиральної машини визначали відповідно до "Програми $\mathrm{i}$ методики проведення випробувань машин для збирання кормових буряків", яку розроблено $\mathrm{i}$ затверджено спільно ІМЕСГ, УкрЦВТ і ДСКБ КВП "Дніпропетровський комбайновий завод" в
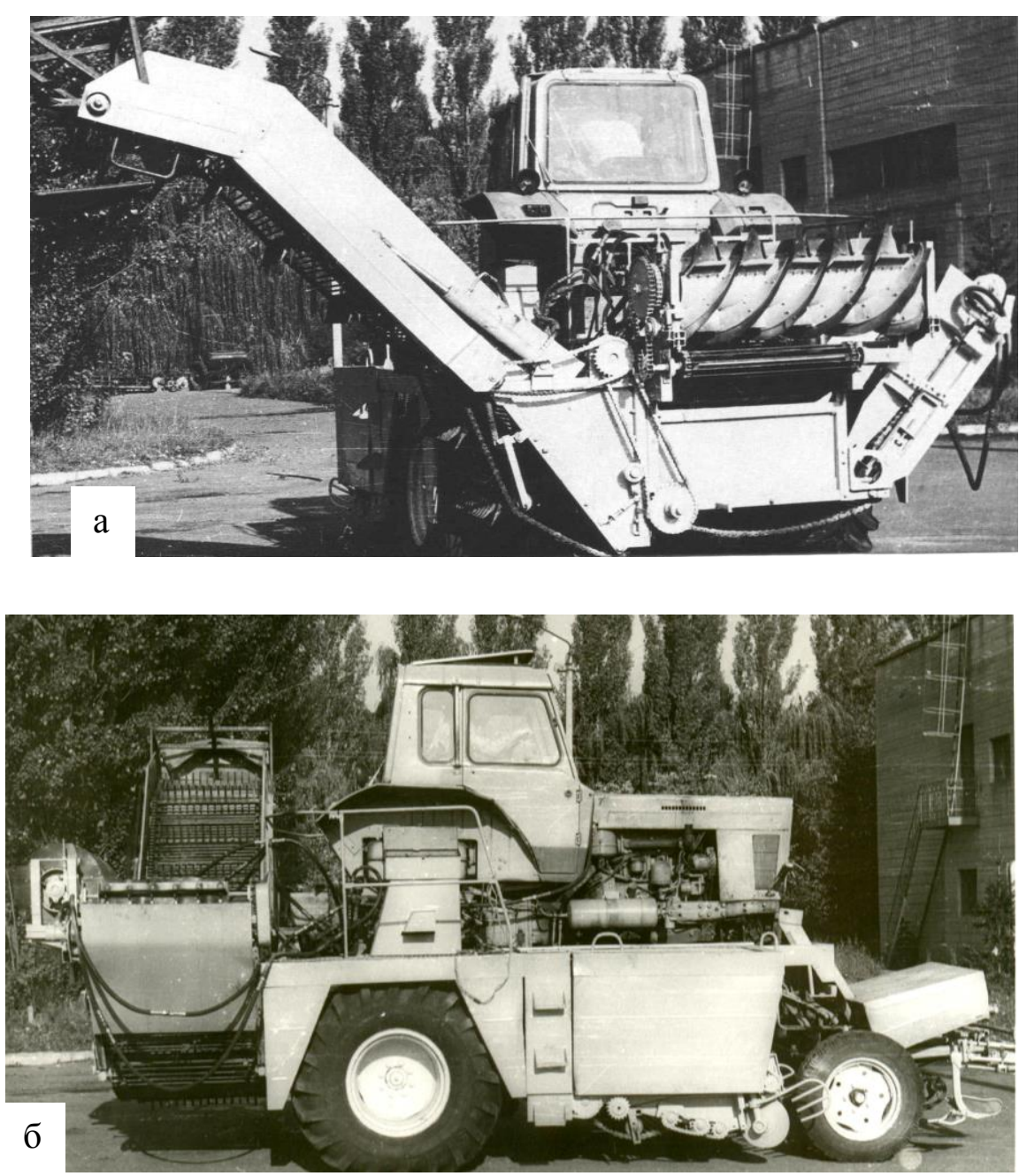

Рис.1. Загальний вигляд модернізованої коренезбиральної машини МКК-6: а - вигляд ззаду; б - вигляд збоку

1987 році на базі галузевого стандарту ГОСТ 70. 8. 6-83.

Було одержано рівняння регресії відповідно в кодованих і натуральних величинах, які характеризують зміну:

- загальної забрудненості вороху коренеплодів рослинними домішками:

$$
\begin{gathered}
Z_{k}=21,9-1,5 x_{1}-2,9 x_{2}+0,2 x_{2}^{2} ; \\
Z_{k}=34,9-0,4 \omega-1,8 d+0,1 d^{2} ; \\
\quad-\text { загальних пошкоджень коренеплодів: } \\
P_{k}=6,5-0,8 x_{1}+0,1 x_{2}+0,07 x_{1}^{2} ; \\
P_{k}=10,4-0,4 \omega+0,08 d+0,01 \omega^{2} ; \\
\text { - забрудненості коренеплодів рослинними домішками: }
\end{gathered}
$$




$$
\begin{aligned}
& Z_{p}=12,6-0,6 x_{1}-1,9 x_{2}+0,1 x_{2}^{2} ; \\
& Z_{p}=19,5-0,3 \omega-1,0 d+0,02 d^{2} ;
\end{aligned}
$$

- кількості налиплого грунту на поверхні тіла коренеплодів

$$
\begin{aligned}
& m_{\rho}=1,6-0,7 x_{1}-0,9 x_{2}+0,3 x_{2}^{2} ; \\
& m_{\rho}=1,5-0,4 \omega-0,08 d+0,06 d^{2} .
\end{aligned}
$$

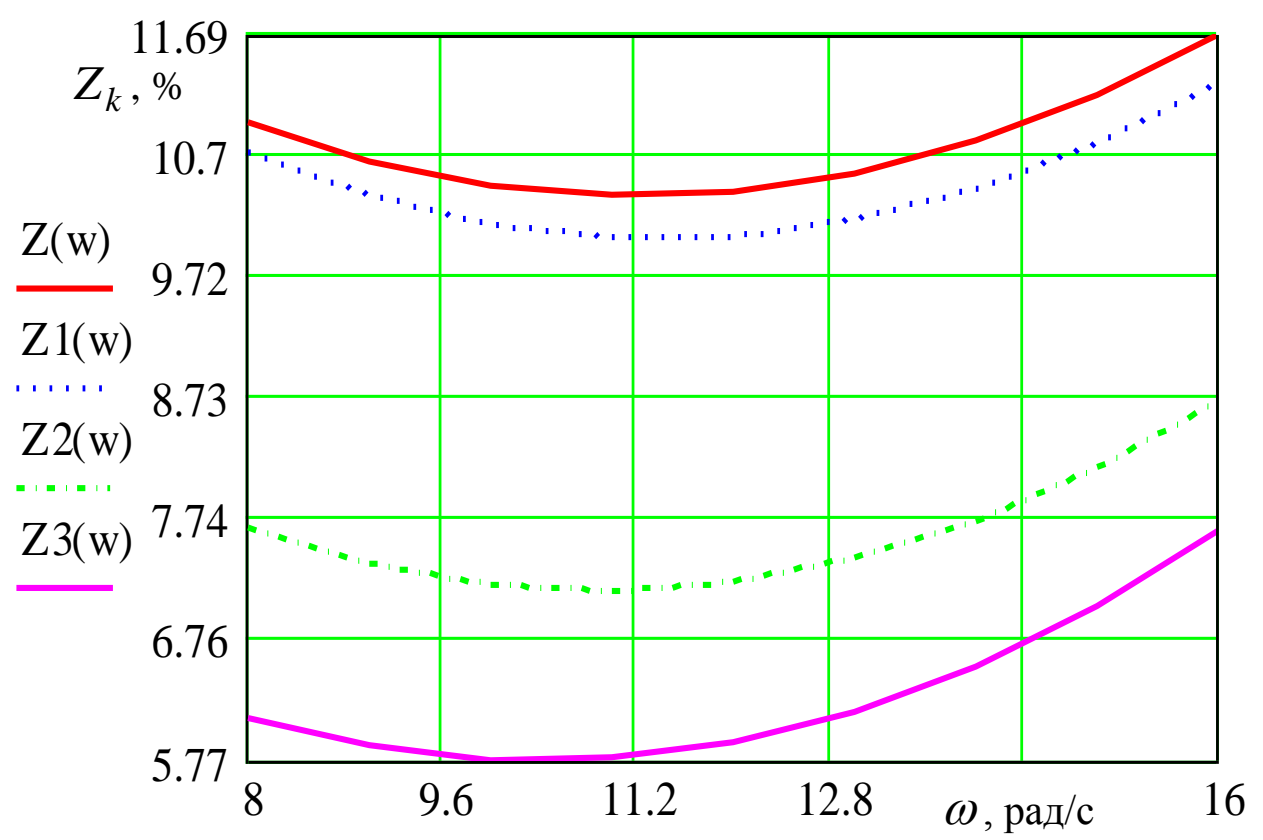

Рис. 2. Залежності загальної забрудненості вороху коренеплодів від зміни кутової швидкості обертання гвинта : Z(w) - без очисних елементів, Z1(w), $\mathrm{Z2}(\mathrm{w})$ i Z3(w) - відповідно для діаметра очисних елементів 2,0; 4,0 i $6.0 \mathrm{MM}$

На рис. 2, 3, 4, 5 наведено відповідно залежності загальної забрудненості вороху коренеплодів, загальних пошкоджень коренеплодів, забрудненості коренеплодів рослинними домішками і кількості налиплого грунту на поверхні тіла коренеплодів залежно від зміни кутової швидкості обертання гвинта та діаметра очисних пружних елементів.

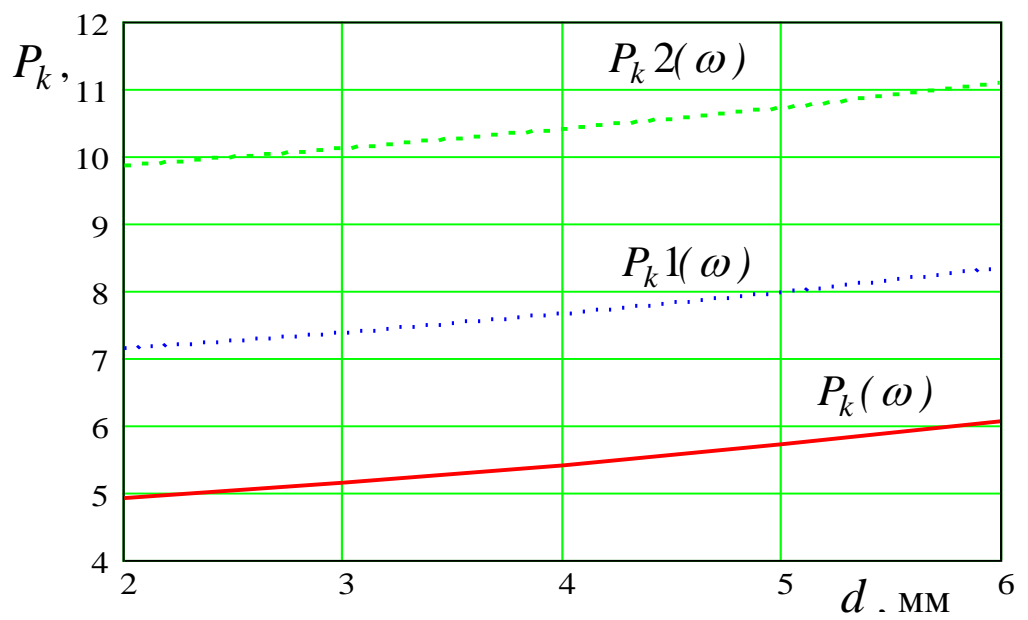

Рис.3. Залежності загальних пошкоджень коренеплодів від діаметра очисних елементів: $P_{k}(\omega), P_{k} 1(\omega)$ і $P_{k} 2(\omega)$ - при кутовій швидкості обертання $\omega$ 
Залежно від збільшення кутової швидкості гвинта загальна забрудненість вороху коренеплодів (рис. 2) також збільшується - при $\omega=9,2$ і 15,8 рад/с для $d=4,0$ мм забрудненість становить 6,9 і 8,6 \% відповідно (криві $\mathrm{Z}(\mathrm{w})$ i $\mathrm{Z2}(\mathrm{w})$, тобто загальна забрудненість вороху збільшується в 1,2 рази.

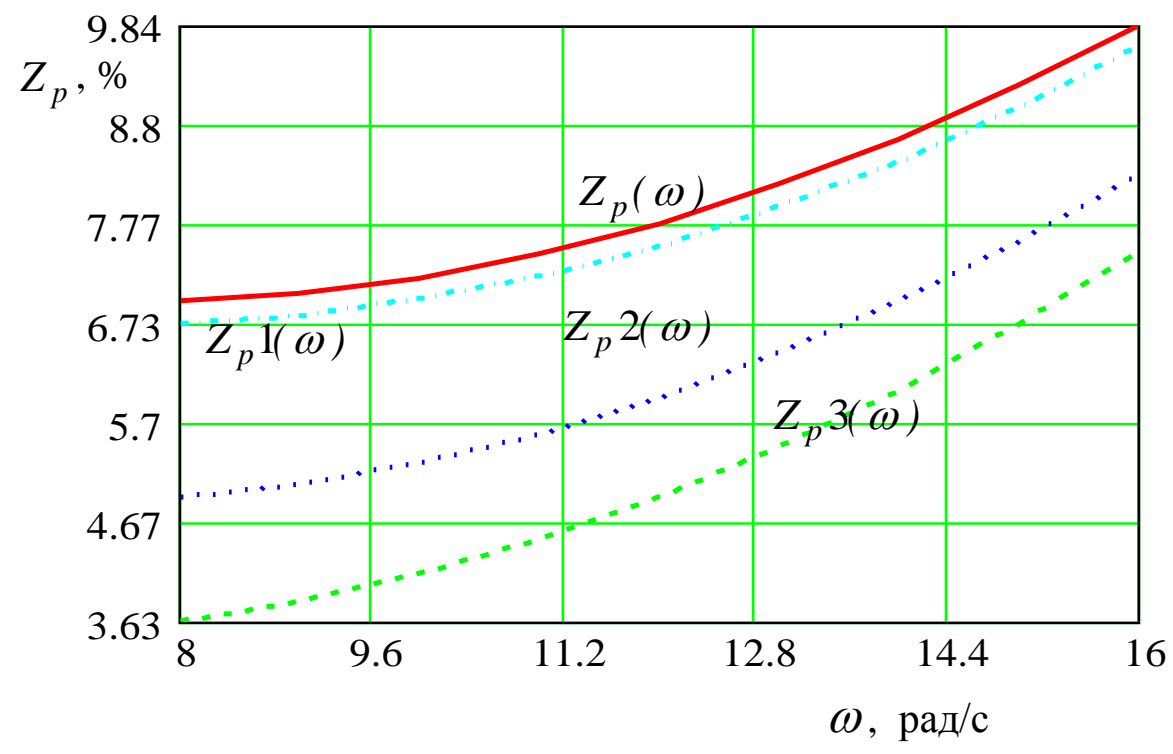

Рис. 4. Залежності забрудненості вороху рослинними домішками від кутової швидкості обертання гвинта $\omega: Z_{p} 1(\omega), Z_{p} 2(\omega)$ і $Z_{p} 3(\omega)-$ відповідно для $d=2,0 ; 4,0$ і 6,0 мм

Аналіз залежностей Z1(w), Z2(w) і Z3(w) показує, що загальна забрудненість вороху коренеплодів залежно від кутової швидкості обертання гвинта змінюється за параболічною функцією, яка має яскраво виражений оптимум - мінімальні значення функції відгуку знаходяться в діапазоні зміни кутової швидкості обертання гвинта $9,6<\omega<11,2$ (рад/с) та відповідно дорівнюють 5,7; 7,2 і 10,1 \% для відповідних діаметрів очисних пружних елементів

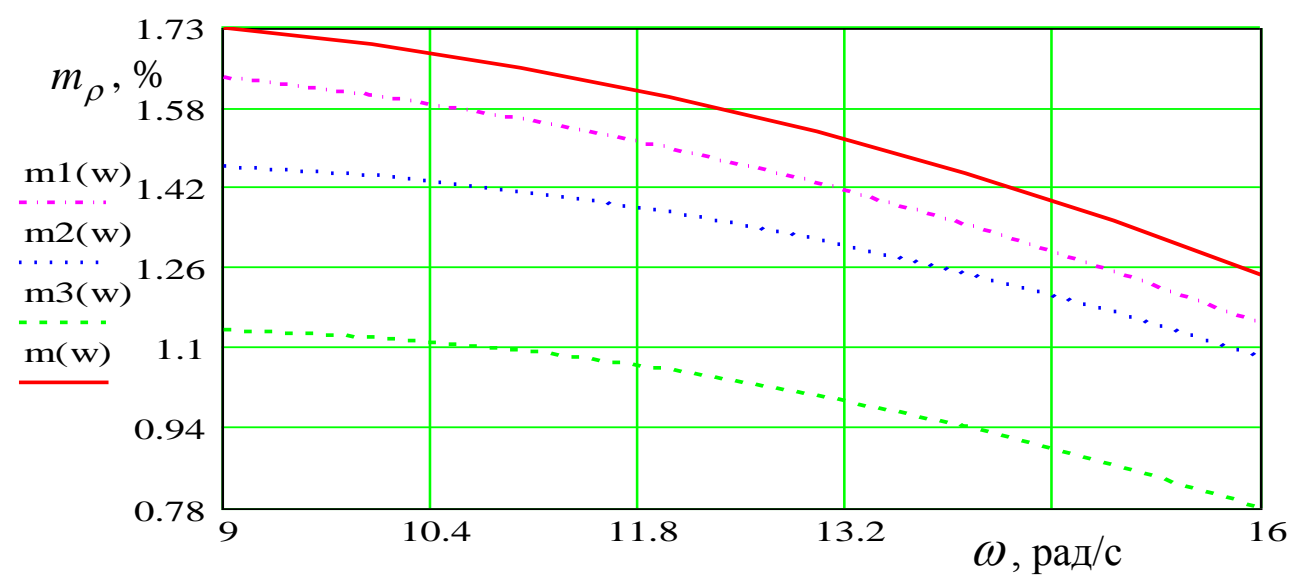

Рис. 5. Залежності кількості налиплого грунту на поверхні тіла коренеплодів від зміни кутової швидкості обертання гвинта: $\mathrm{m}(\mathrm{w})$ - без очисних елементів; m1(w), m2(w) i m3(w) - відповідно для діаметра очисних елементів 2,0; 4,0 і 6,0 мм

$d=6,0 ; 4,0$ і 2,0 мм. 
Порівняльний аналіз наведеної залежності Z(w) з залежностями Z1(w), Z2(w) i Z3(w) показує, що встановлення на барабані гвинта очисних пружних елементів зменшує загальну забрудненість вороху в $1,4-1,9$ рази, а значне зменшення спостерігається при значенні $d \geq 4$ мм.

Аналізуючи залежності рис. 3 , можна зробити висновок, що домінуючим фактором, який значно впливає на зміну параметра оптимізації, є кутова швидкість обертання гвинта $\omega$ - із іiі збільшенням загальні пошкодження зростають від 5,2 \%, $\omega=9,6$ рад/ с до 11,1 \% при значенні кутової швидкості обертання гвинта $\omega=15,8$ рад/, тобто пошкодження збільшуються у середньому у 2,1 рази. Характер впливу діаметра очисних елементів $d$ на зміну загальних пошкоджень коренеплодів незначний: так, для значення $\omega=12,5$ рад/с пошкодження становлять 7,6 і 8,3\% (криві $\left.P_{k}(\omega), P_{k} 1(\omega)\right)$ при відповідних значеннях $d=4$ і 6 мм, тобто приріст пошкоджень складає у середньому $0,7 \%$.

При встановленій кутовій швидкості обертання гвинта $\omega=12,5$ рад/с забрудненість вороху рослинними домішками становить 8,1 і 4,6 \% відповідно для $d=4$ і 6 мм, (рис. 4 , криві $Z_{p} 2(\omega)$ і $\left.Z_{p} 3(\omega)\right)$, тобто зі збільшенням діаметра очисних елементів $Z_{p}$ зменшується у 1,8 рази.

Аналіз рис. 5 показує, що основним фактором, який впливає на кількість налиплого грунту на поверхні тіла коренеплодів, є діаметр очисних пружних елементів $d-3$ його збільшенням кількість налиплого грунту на поверхні тіла коренеплодів значно зменшується при всіх значеннях кутової швидкості обертання гвинта $\omega$, значний вплив якої на параметр оптимізації спостерігається при $\omega \geq 12,5$ рад/с. Так, при значенні $\omega=9,2$ і 12,5рад/с маса налиплого грунту становить 1,8 i $1,7 \%$ для $d=2,0$ мм, тобто зменшення кількості налиплого грунту незначне і становить $0,1 \%$ (криві $\mathrm{m} 1(\mathrm{w})$ i $\mathrm{m} 2(\mathrm{w})$, а при $\omega=15,8$ рад/с маса налиплого грунту - $1,4 \%$, тобто зменшується у середньому на $0,35 \%$. При значенні $d=6,0$ мм кількість налиплого грунту на поверхні тіла коренеплодів порівняно $3 d=2,0$ мм зменшується приблизно в 1,5-1,8 рази.

Результати випробування коренезбиральної машини подано в таблиці згідно 3 протоколом випробувань.

Таблиця 1

Показники якості роботи коренезбиральної машини

\begin{tabular}{|c|c|c|}
\hline \multirow{2}{*}{ Показники } & \multicolumn{2}{|c|}{ Значення показників } \\
\cline { 2 - 3 } & Коренезбиральна машина & 3а Т3 (ВВ) \\
\hline Робоча швидкість руху машини, м/с & 1,6 & 1,6 \\
\hline \multicolumn{2}{|c|}{ Якість підкопування і підбирання коренеплодів, \%: } \\
\hline зібрано машиною & 99,2 & 1,5 \\
втрати & 0,8 & \\
\hline Склад вороху зібраних коренеплодів, \%: & 8,0 \\
\hline коренеплодів & 97,5 & \\
домішок, всього: & 2,5 & 3,0 \\
в тому числі: & 0,6 & \\
землі & 1,4 & \\
рослинних домішок & 0,4 & 8,0 \\
землі на коренеплодах & 0,1 & 7,0 \\
гички на головках коренеплодів & 4,5 \\
\hline Пошкодження коренеплодів, \% & 4,3 & \\
\hline сильнопошкоджених & \multicolumn{2}{|c|}{} \\
слабопошкоджених &
\end{tabular}

Аналіз таблиці показує, що якість роботи коренезбиральної машини задовольняє вихідні вимоги, ефективність збирання і показники якості роботи задовільні: кількість пошкоджених коренеплодів складає $8,8 \%$, що у 1,8 рази нижче допустимих норм, а загальна кількість домішок в зібраному воросі дорівнює 2,5 \% при допустимому значені 8,0 \% згідно з вихідними вимогами. Крім того, застосування відминальних вальців дозволило зменшити кількість 
залишків гички на головках коренеплодів до 0,1 \% проти 3,0 \% згідно з вихідними вимогами, що у 1,5 рази менше допустимих норм.

Показники якості роботи коренезбиральної машини при польових випробуваннях визначені до загальної маси зібраних коренеплодів.

\title{
Висновок
}

Таким чином, за рахунок встановлення гвинтового конвеєра 3 очисними пружними елементами і очисної пальчикової гірки, відбувається додаткова інтенсифікація процесу відокремлення домішок від коренеплодів за рахунок динамічної взаємодії очисних пружних елементів із налиплим грунтом, при цьому кількість налиплого грунту на поверхні тіла коренеплодів зменшується приблизно в 1,5-1,8 рази.

Польові випробування коренезбиральної машини, яку обладнано очисною системою, показали задовільні результати ії роботи, при цьому основні показники агротехнічної оцінки не перевищують межу вихідних вимог.

\section{Інформаційні джерела}

1. Свеклоуборочные машины: история, конструкция, теория, прогноз / Л.В. Погорелый, М.В. Татьянко. - К.: Феникс, 2004. - 232 с.

2. Барановський В.М., Паньків М.Р. Конструктивно-технологічні принципи адаптованого застосування коренезбиральних машин // 3б. наук. праць 1-ої міжн. наук.-практ. конф. “Динаміка, міцність і надійність сільськогосподарських машин”. - ТДТУ, 2004. - С. 192-198.

3. Гандзюк М.О., Осуховський В.М., Ткаченко І.Г., Гевко Р.Б. Результати випробувань модернізованої коренезбиральної машини КС-6Б // Сільськогосподарські машини. Зб. наук. ст., вип. 7. - Луцьк: Ред.-вид. відділ ЛДТУ, 2000. - С. 25-30.

4. Bulich C. Biotechnische Einflussfaktorenauf die Köpfgualitätvon Zuckerrüben. - Inang. Diss. - Bonn, 1990. - 153 s.

5. Паньків М.Р., Дубчак Н.А., Барановський В.М. Очисна система вороху коренеплодів // Вісник ХНТУСГ. - Вип. 59. "Механізація сільськогосподарського виробництва". - Том 1. Харків, 2007. - С. 33-36.

Dubchak N.A., Semeniv I.I., Nosko V.L.

SE NULES of Ukraine "Berezhany Agrotechnical Institute"

\section{RESULTS OF EXPERIMENTAL RESEARCHES OF CLEANSING SYSTEM TO LOTS OF ROOT CROPS}

\begin{abstract}
The article presents the results of field experimental tests of the modernized rootharvesting machine MKK-6, which is equipped with a combined system for cleaning fodder beets from various contaminants during their harvesting. Based on experimental results, regression equations are derived, which characterize the change of total contamination of heap of root crops with different impurities and graphical dependences of total contamination of heap of fodder beets, root damage, contamination of root crops with plant remains the diameter of the cleaning elastic elements. When analyzing the dependences, it was found that the total contamination of the heap of roots, depending on the angular velocity of rotation of the screw varies according to the parabolic function, which has a pronounced optimum. It is also reported that the main factor that affects the amount of sticky soil on the surface of the body of roots is the diameter of the cleaning elastic elements. With its increase, the amount of sticky soil on the body surface of the roots decreases significantly at all values of the angular velocity of rotation of the screw.
\end{abstract}

Key words: separating working body, transport-technological system, root crops, heap, rootharvesting machine, screw, angular velocity, cleaning element.

\section{Дубчак Н.А., Семенив И.И., Носко В.Л.}

ОП НУБиП Украины «Бережанский агротехнический институт»

\section{РЕЗУЛЬТАТЫ ЭКСПЕРИМЕНТАЛЬНЫХ ИССЛЕДОВАНИЙ ОЧИСТНОЙ СИСТЕМЫ ВОРОХА КОРНЕПЛОДОВ}

Аннотация. В статье приведены полученные результаты проведенных полевых экспериментальных испытаний модернизированной корнесобиральной машины МКК-6, 
которую оборудовано комбинированной системой для очистки кормовой свекльы от разного рода загрязнений при их уборке. На основе экспериментальных результатов выведено уравнение регрессии, характеризующие изменение общей загрязненности вороха корнеплодов различными примесями и построено графические зависимости общей загрязненности вороха кормовой свекль, поврежденых корнеплодов, загрязненности корнеплодов растительными остатками и количества налипшего грунта на поверхности тела корнеплодов в зависимости от изменения угловой скорости вращения винта и диаметра очистных упругих элементов. При анализе зависимостей вылялено, что общая загрязненность вороха корнеплодов в зависимости от угловой скорости вращения винта изменяется по параболической функиии, которая имеет ярко выраженный оптимум. Также определено, что основным фактором, который влияет на количество налипшего грунта на поверхности тела корнеплодов является диаметр очистных упругих элементов. При его увеличении количество налипшего грунта на поверхности тела корнеплодов значительно уменьшается при всех значениях угловой скорости вращения винта.

Ключевые слова: сепарирующий рабочий орган, транспортно-технологическая система, корнеплоды, ворох, корнеуборочная машына, винт, угловая скорость, очистительный элемент. 